\title{
Mindkét végén befogott gerenda tehetetlenségi föirány körüli hajlító rezgéséhez tartozó sajátfrekvenciájának vizsgálata egyszabadságfokú modell és végeselemes számítás alapján
}

\section{Investigation of the Eigenfrequency of the Bending Vibration of the Beam Clamped at Both Ends Around the Principle Directions of Inertia Based on a Single- Degree Freedom Model and a Finite Element Method} Analysis

\author{
VADAI Zs. ${ }^{1}$, HAJDU S. ${ }^{2}$, KOVÁCS I. ${ }^{3}$ \\ ${ }^{1}$ University of Debrecen, Faculty of Engineering, Department of Civil Engineering, vadai@eng.unideb.hu \\ ${ }^{2}$ University of Debrecen, Faculty of Engineering, Department of Mechanical Engineering, \\ hajdusandor@eng.unideb.hu \\ ${ }^{3}$ University of Debrecen, Faculty of Engineering, Department of Civil Engineering, dr.kovacs.imre@gmail.com
}

\begin{abstract}
Absztrakt. Jelen cikkben mindkét végén befogott, téglalap keresztmetszetú gerendák hajlító rezgéséhez tartozó sajátfrekvenciák számítási módszereivel foglalkoztunk. Az említett sajátfrekvenciákat a gerenda egyszabadságfokú modelljén analitikusan, valamint a térbeli szilárdtest-, és a térbeli rúd modellek esetében végeselemes modális rezgésvizsgálattal határoztuk meg. Bemutattuk az analitikus modell jellemzőinek kiszámításának módját, majd egy konkrét példa esetében kiszámítottuk a sajátfrekvenciát. Ismertettük a modális jellemző́k fogalmát, a továbbiakban az elôbbi gerenda szilárdtest-, és rúd modellje alapján meghatároztuk a sajátfrekvenciáját. A bemutatott módszerekkel további 11 esetben számítottuk ki, és vetettük össze a különböző módon felvett modellekhez tartozó megoldásokat.
\end{abstract}

\begin{abstract}
In this study, we have dealt with the calculation methods of the eigenfrequencies associated with the bending vibrations of rectangular-shaped beams clamped at both ends. Said eigenfrequencies were determined analytically in the single-degree of freedom model of the beam and the case of the three-dimensional solid and three-dimensional rod models by finite element modal vibration analysis. We presented the calculation method of the characteristics of the analytical model and then calculated the eigenfrequency for a concrete example. We have described the concept of modal characteristics, and in the following, we have determined its natural frequency based on the solid-beam and rod models of the former beam. We calculated and compared the solutions belonging to the models recorded in different ways in 11 additional cases of the presented methods.
\end{abstract}


International Journal of Engineering and Management Sciences (IJEMS) Vol. 6. (2021). No. 3

Kulcsszavak: Végeselem módszer, gerenda, sajátfrekvencia,

Keywords: Finite element method, beam, eigenfrequencies,

\section{Bevezetés}

A számítástechnika fejlődése lehetővé tette, hogy a tartószerkezeti tervezés és ellenőrzés során a szerkezet egészét egy teljes, térbeli (továbbiakban globális) modell alapján vizsgáljuk. Az ezt megelőző szemlélet szerint, a teljes szerkezetet a tervező szerkezeti elemekre bontotta és ezeket lokális modelleken végzett számítások alapján méretezte, ellenőrizte. Belátható, hogy a mérnöki feladatok méretének növekedésével, egyre fontosabbá vált a globális viselkedés figyelembevétele, ugyanakkor kisebb létesítmények esetében továbbra is van létjogosultsága a szerkezeti elemekre bontásnak és azok lokális modelleken végzett tervezésének, valamint ellenőrzésének. Nagyméretű mérnöki feladatoknál, globális modell alkotás esetén is célszerű előtervezésnél, illetve a véglegesített nagyfontosságú szerkezeti elemek ellenőrzésnél a lokális szemléletet követni [1]. A rendelkezésreálló nagy számítási kapacitás és fejlett komplex szerkezeti modellezést lehetővé tevő végeselem programok mellett is szükség van olyan közelítő eljárásokra, melyekkel gyorsan, megbecsülhető a számítások eredménye. Tanulmányunkban mindkét végén befogott, téglalap keresztmetszetű gerendák, a tehetetlenségi főirány körüli hajlító rezgéséhez tartozó sajátfrekvenciák meghatározásával foglalkozunk. A sajátkörfrekvencia a legtöbb dinamikai számításnak [2], valamint szabványos méretezési eljárásnak bemenő paramétere [1], így meghatározása kulcsfontosságú. A sajátfrekvenciát kiszámítjuk a gerenda egyszabadságfokú modelljén, valamint modális végeselemes rezgés vizsgálattal meghatározzuk az említett hajlító rezgéshez tartozó sajátfrekvenciát többszabadságfokú szilárdtest- és rúd modellen egyaránt. (A [3,4] hivatkozott irodalmakban található példa a nem elhanyagolható tömegű gerendák egyszabadságfokú modellen alapuló rezgésvizsgálatára.) Végül megvizsgáljuk különböző téglalap keresztmetszetű és hosszúságú gerendák esetén, az egyes modellek alapján kapott sajátfrekvenciák közötti eltérést.

\section{Anyagmodell}

Az egyszabadságfokú- és a végeselem modellek esetében is izotróp lineárisan rugalmas anyagmodellt alkalmaztunk az alábbi állandókkal:

- rugalmassági modulus: $E=210 G P a$,

- Poisson tényező: $v=0,3$,

- sűrűség: $\rho=7850 \mathrm{~kg} / \mathrm{m}^{3}$. 


\section{A szerkezet geometriája}

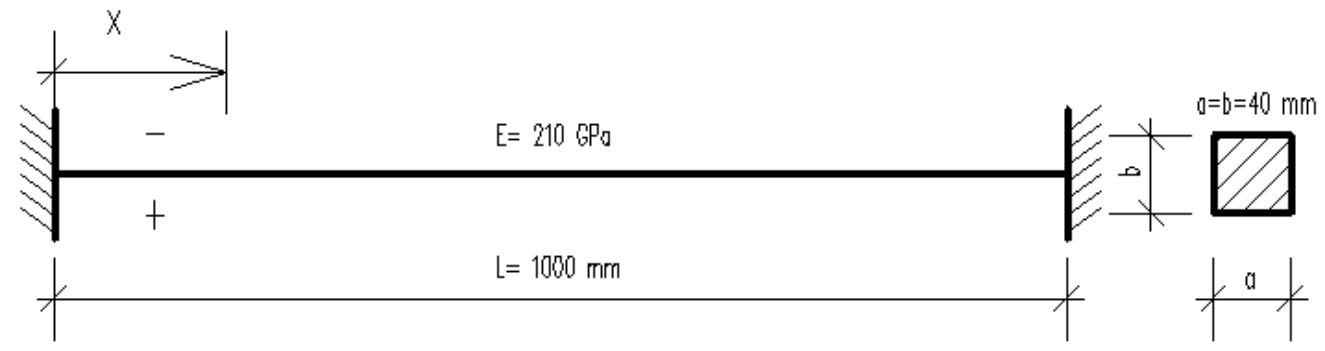

1. ábra: Mindkét végén befogott acél gerenda

Mivel $a=b=40 \mathrm{~mm}$, a gerenda kiindulási keresztmetszete négyzet, melynek speciális tulajdonsága, hogy a súlypontban felvett tetszőleges irányú tengelyekre vett másodrendű nyomatéka az oldalhossz negyedik hatványának a tizenkettede (az állítás helyességének bizonyítása és további általánosítása megtalálható a Függelékben). Az előbbi speciális tulajdonságot a továbbiakban nem használjuk, így eredményeink téglalap szelvényre is igazak lesznek.

\section{Az egyszabadságfokú modell}

Az egyszabadságfokú modell esetén a gerenda lengését, a szilárdsági tengely középső pontjának függőleges irányban történő egyszabadságfokú csillapítatlan szabad rezgésével modellezzük. Az 1. ábrán látható szerkezetnek megfeleltetjük a 2. ábrán adott rendszert, melynek $k$ és $m_{0}$ jellemzője meghatározandó.

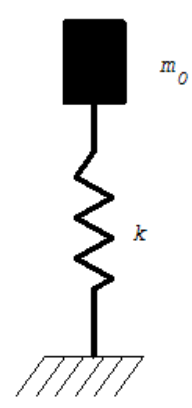

\section{2. ábra: Az egyszabadságfokú modell}

A $k$ rugómerevséget, a gerenda középső pontjában ható $F$ koncentrált erőnek és a hatására kialakuló függőleges eltolódásnak a hányadosaként értelmezzük. Az $m_{0}$ redukált tömeget abból a feltételből határozzuk meg, hogy a modellezendő $m_{0}$ tömegű középső pontnak a mozgási energiája megegyezik a teljes gerenda mozgási energiájával. Mindkét mennyiség számításához szükség van gerenda szilárdsági tengelyének középső pontjában ható koncentrált erő által okozott függőleges lehajlás függvényére.

\subsection{A rugómerevség meghatározása}

Rögzítsünk egy balsodrású koordinátarendszert a bal oldali fix támaszhoz úgy, hogy az $x$ tengely jobbra mutatva essen egybe a gerenda szilárdsági tengelyével, míg az y lefelé mutasson (1. ábra). A lehajlás 
függvényt megkapjuk a nyomaték függvény ellentettjének kétszeri integrálásával, ahol az integrálási állandókat abból a feltételből határozzuk meg, hogy a függőleges eltolódás és az elfordulás egyaránt zérus értékű a támaszoknál [5]. Az $x(x \in[0 ; L])$ koordinátájú pont függőleges eltolódását (lehajlását) a tartó közepén ható $F$ koncentrált erőből az alábbi függvény adja meg:

$$
e_{F}(x)=\left\{\begin{array}{cc}
-\frac{F \cdot x^{3}}{12 \cdot E \cdot I}+\frac{F \cdot L \cdot x^{2}}{16 \cdot E \cdot I}, & \text { ha } 0 \leq x \leq \frac{L}{2} \\
-\frac{F \cdot(L-x)^{3}}{12 \cdot E \cdot I}+\frac{F \cdot L \cdot(L-x)^{2}}{16 \cdot E \cdot I}, & \text { ha } \frac{L}{2} \leq x \leq L .
\end{array}\right.
$$

A rugómerevséget az előbbiek alapján a következő összefüggésből számítjuk az 1. ábrán megadott értékek felhasználásával:

$$
k=\frac{F}{e_{F}(L / 2)}=\frac{192 \cdot E \cdot I}{L^{3}}=8601,6 \frac{\mathrm{kN}}{\mathrm{m}}
$$

ahol I a hajlítás tengelyére vett másodrendű nyomatéka a keresztmetszetnek:

$$
I=\frac{a \cdot b^{3}}{12}=\frac{40^{4}}{12}=213333,33 \mathrm{~mm}^{4}
$$

\subsection{A redukált tömeg meghatározása}

Tételezzük fel, hogy a gerenda szilárdsági tengelyének $x$ koordinátájú pontja függőleges elmozdulását a $t$ pillanatban az $e(x ; t)$ függvény határozza meg, melyet a következő alakban írhatunk fel:

$$
e(x ; t)=f(t) \cdot e_{F}(x),
$$

ahol jelentse $f(t)$ tettszőleges (valós) függvényét az időnek, ekkor az $x$ koordinátájú pont sebességét a $t$ pillanatban az $e(x ; t)$ függvény első idő szerinti deriváltjaként kapjuk, azaz:

$$
v(x ; t)=\dot{e}(x ; t)=e_{F}(x) \cdot \dot{f}(t),
$$

a szilárdsági tengely középső pontjának sebességére következő kifejezés adódik:

$$
v(L / 2 ; t)=\dot{e}(L / 2 ; t)=e_{F}(L / 2) \cdot \dot{f}(t) .
$$

A középső keresztmetszetbe redukált, egyelőre ismeretlen $m_{0}$ tömeg mozgási energiája ekkor:

$$
E_{m 0}=\frac{1}{2} \cdot m_{0} \cdot v^{2}(L / 2 ; t)=\frac{1}{2} \cdot m_{0} \cdot e_{F}^{2}(L / 2) \cdot \dot{f}^{2}(t) .
$$

Az elemi $d x$ hosszúságú $x$ koordinátájú rúdelem mozgási energiája:

$$
d E_{m}=\frac{1}{2} \cdot a \cdot b \cdot \rho \cdot v^{2}(x ; t) \cdot d x=\frac{1}{2} \cdot a^{2} \cdot \rho \cdot e_{F}^{2}(x) \cdot \dot{f}^{2}(t) \cdot d x
$$

ahol $\rho=7850 \mathrm{~kg} / \mathrm{m}^{3}$ az acél sűrűsége. A teljes gerenda mozgási energiáját a (8) kifejezés rúdhossz menti integrálásával kapjuk:

$$
E_{m}=\int_{0}^{L} \frac{1}{2} \cdot a \cdot b \cdot \rho \cdot e_{F}{ }^{2}(x) \cdot \dot{f}^{2}(t) \cdot d x=\frac{1}{2} \cdot a \cdot b \cdot \rho \cdot \dot{f}^{2}(t) \cdot \int_{0}^{L} e_{F}{ }^{2}(x) \cdot d x
$$

A (7) és (9) egyenletek megfelelő oldalait egymással egyenlővé téve, $m_{0}$-ra a következő kifejezés adódik: 
International Journal of Engineering and Management Sciences (IJEMS) Vol. 6. (2021). No. 3

$$
m_{0}=\frac{a \cdot b \cdot \rho}{e_{F}^{2}(L / 2)} \cdot \int_{0}^{L} e_{F}^{2}(x) \cdot d x .
$$

Kihasználva a szerkezet és a terhelés szimmetriáját, a következő kifejezést kapjuk:

$$
m_{0}=\frac{2 \cdot a \cdot b \cdot \rho}{e_{F}^{2}(L / 2)} \cdot \int_{0}^{L / 2} e_{F}^{2}(x) \cdot d x .
$$

Az (1) egyenletet beírva (11)-be, a jobb oldalon álló határozott integrált kiszámítva $m_{0}$ értékét az alábbi kifejezéssel számíthatjuk:

$$
m_{0}=\frac{13}{35} \cdot a \cdot b \cdot \rho \cdot L=4,665 \mathrm{~kg}
$$

\subsection{Sajátkörfrekvencia és sajátfrekvencia}

A rugómerevség és a redukált tömeg ismeretében az egyszabadságfokú rendszer sajátkörfrekvenciája az alábbi képlettel számítható [3]:

$$
\omega_{0}=\sqrt{\frac{k}{m_{0}}}=1357,87 \mathrm{~s}^{-1} .
$$

A sajátkörfrekvenciából meghatározható az $f_{0}$ sajátfrekvencia:

$$
f_{0}=\frac{\omega_{0}}{2 \pi}=216,11 \mathrm{~Hz}
$$

A (2) és (12) egyenleteket a (13), majd a (14) kifejezésbe helyettesítve $\omega_{0}$ és $f_{0}$ értéke az alábbi összefüggésekkel határozható meg:

$$
\begin{aligned}
& \omega_{0}=4 \cdot \sqrt{\frac{35}{13}} \cdot \sqrt{\frac{E}{\rho}} \cdot \frac{b}{L^{2}} \cong 6,563 \cdot \sqrt{\frac{E}{\rho}} \cdot \frac{b}{L^{2}}, \\
& f_{0}=\frac{2}{\pi} \cdot \sqrt{\frac{35}{13}} \cdot \sqrt{\frac{E}{\rho}} \cdot \frac{b}{L^{2}} \cong 1,045 \cdot \sqrt{\frac{E}{\rho}} \cdot \frac{b}{L^{2}} .
\end{aligned}
$$

A (15) és (16) formulákból látható, a sajátkörfrekvencia, valamint a sajátfrekvencia egyszabadságfokú modell esetén független a téglalap szelvény hajlítási tengellyel párhuzamos méretétől (szélességétől).

\section{A modális jellemzők végeselemes meghatározása}

Egy $n$-szabadságfokú rendszer szabad rezgését az alábbi lineáris, általános, másodrendű, állandóegyütthatós, homogén mátrix-differenciál egyenlet írja le:

$$
\underline{\underline{\boldsymbol{M}}} \cdot \underline{\ddot{\boldsymbol{x}}}(t)+\underline{\underline{\boldsymbol{K}}} \cdot \underline{\boldsymbol{x}}(t)=\underline{\mathbf{0}} ; \underline{\boldsymbol{x}}(t) \in \mathbb{R}^{n} ; \underline{\underline{\boldsymbol{M}}}, \underline{\underline{\boldsymbol{K}}} \in \mathbb{R}^{n \times n},
$$


ahol $\underline{\underline{\boldsymbol{M}}}$ a tömegmátrix, $\underline{\underline{\boldsymbol{K}}}$ a merevségimátrix, valamint $\underline{\boldsymbol{x}}(t)$ a csomóponti elmozdulások vektora. Legyen $\underline{\boldsymbol{x}}(t)=e^{i \omega_{0} t} \cdot \underline{\boldsymbol{X}}$, ezt, illetve ennek második deriváltját behelyettesítve a (17) egyenletbe, majd mindkét oldalt osztva $e^{i \omega t} \neq 0$ értékkel a következő egyenletet kapjuk:

$$
\left(\underline{\underline{\boldsymbol{K}}}-\omega_{0}^{2} \cdot \underline{\underline{\boldsymbol{M}}}\right) \cdot \underline{\boldsymbol{X}}=\underline{\mathbf{0}} .
$$

A (18) kifejezés az $\underline{\boldsymbol{X}}$ elemeire nézve, egy lineáris homogén egyenletrendszer (általános sajátérték feladat), melynek a Cramer-szabály szerint, akkor van a triviálistól különböző megoldása, ha az együttható mátrix determinánsa zérus, azaz:

$$
\left|\underline{\underline{\boldsymbol{K}}}-\omega_{0}^{2} \cdot \underline{\underline{\boldsymbol{M}}}\right|=0
$$

A (19) egyenlet $\omega_{0}^{2}$-re nézve $n$-ed fokú, melynek a $\underline{\underline{K}}$ és az $\underline{\underline{\boldsymbol{M}}}$ mátrixok szimmetrikus és pozitív definit volta miatt $n$ számú pozitív megoldása adódik [3]. A pozitív $\omega_{0 i}-\mathrm{k}(1 \leq i \leq n ; i \in \mathbb{Z})$ a rendszer sajátkörfrekvenciái, a hozzájuk tartozó $\underline{X}_{i}$ vektorok pedig lengésképek vagy módusok. A sajátkörfrekvenciákat és a lengésképeket a rendszer modális jellemzőinek nevezzük.

\subsection{Modális jellemzők meghatározása a szilárdtest modellen}

A szilárdtest modellek az Ansys 2020 R2 program felhasználásával készültek. A szilárdtest modell megalkotása (az anyagtulajdonságok megadása mellett,) a fix támaszok definiálását jelentette gerendának megfelelő hasáb véglapjain.

\section{3. ábra: A szilárdtest modell}

A szabályos geometria miatt tökéletes hexa hálót sikerült létrehozni, melynek elemméretét 4 mm-re vettük fel. (Vizsgáltunk kisebb elemméretet is, de ez nem okozott számottevő eltérést az eredményeinkben.)

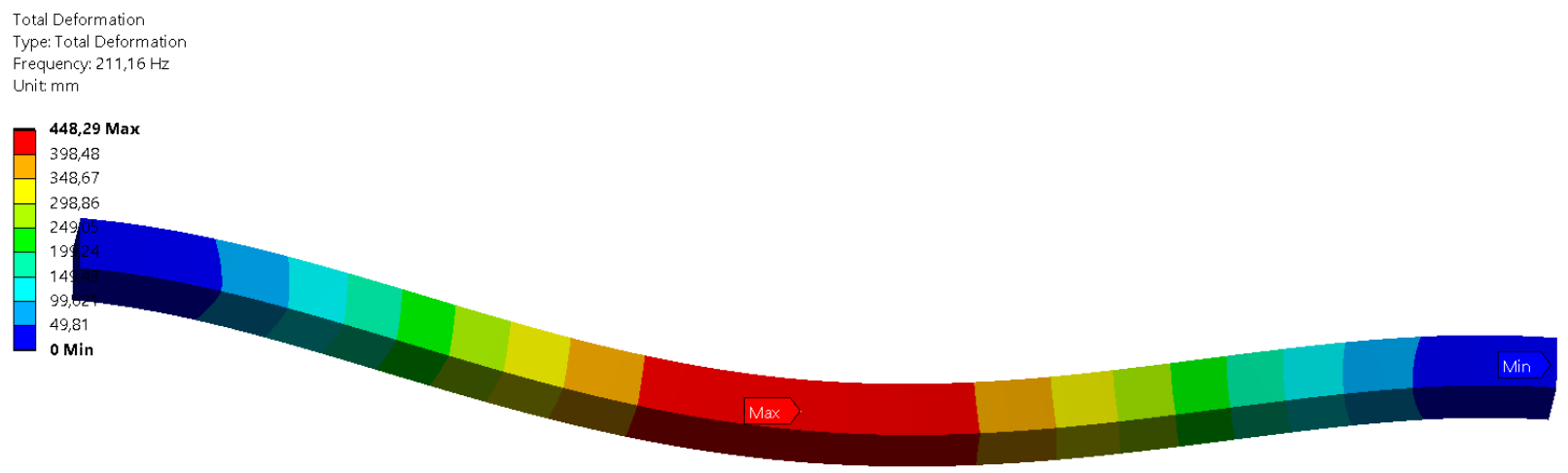

4. ábra: Sajátfrekvencia a szilárdtest modellen

A számítást az első hat lengésképre futtattuk le, majd kiválasztottuk a középső pont maximális eltolódásának megfelelő (fél hullám) módushoz tartozó sajátfrekvenciát, ami $f_{0 s}=211,16 \mathrm{~Hz}$-re adódott. A négyzet keresztmetszetek esetében azt tapasztaltuk, hogy az eltolódás az egyik átlóval 
párhuzamosan jött létre. Ez nem jelent problémát, hiszen az átlókra vett inercia egyenlő az oldalfelező pontokat összekötő szimmetriatengelyekre számított másodrendű nyomatékokkal (lásd Függelék).

\subsection{Modális jellemzők meghatározása a rúd modellen}

A sajátfrekvenciákat a rúd modellek esetében az AxisVM X5 4f. programmal számítottuk ki. A rúd modellek elkészítése során (az anyagparamétereken túl,) a szilárdsági tengelyt, a keresztmetszetet, a csomópontok elmozdulási szabadságfokát, valamint a rúdvégek fix megfogását kellett definiálni. A csomópontok szabadsági fokát a térbeli rúd modellnek megfelelően 6-nak vettük fel. A rudat a hálózás során 20 részre osztottuk fel. [6] alapján a megfelelő pontosság eléréséhez elegendő, ha minden rezgési félhullámhoz 4 elemosztás tartozik. Mivel az egy félhullámhoz tartozó sajátfrekvenciát kerestük, így az alkalmazott felosztás megfelelő volt.
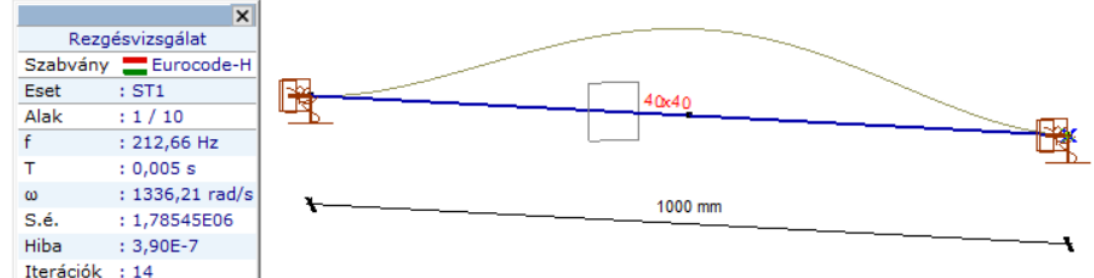

5. ábra: Sajátfrekvencia a rúd modellen

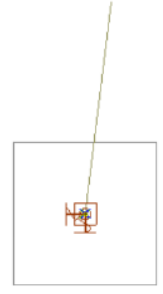

Az 5. ábrán láthatjuk a rúd modell számításának az eredményét, mely szerint a sajátfrekvencia $f_{0 r}=$ 212,66 Hz. A szilárdtest modellekhez hasonlóan az elmozdulás ferde síkban jött létre (5. ábra), a négyzet 2. fejezetben részletezett tulajdonsága miatt (lásd Függelék).

\section{További eredmények, következtetések}

A 3. és 4. fejezetekben bemutatott módszerek alapján, különböző téglalap keresztmetszetű és hosszúságú gerendák, főirány körüli hajlító rezgéseihez tartozó sajátfrekvenciáit határoztuk meg. A számításaink eredményeit a következő táblázatokban foglaltuk össze.

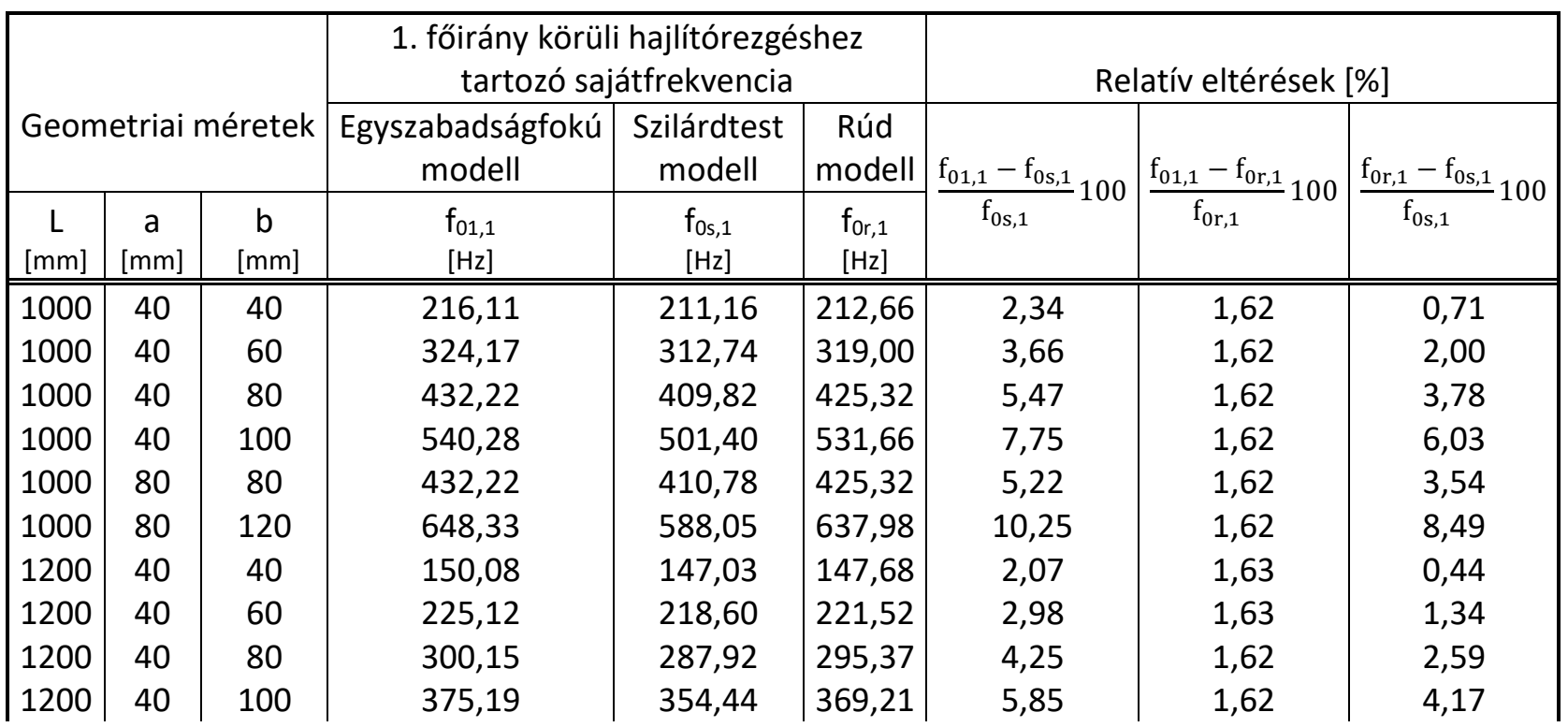


International Journal of Engineering and Management Sciences (IJEMS) Vol. 6. (2021). No. 3

DOI: 10.21791/IJEMS.2021.3.6.

\begin{tabular}{|c|c|c|c|c|c|c|c|c|}
1200 & 80 & 80 & 300,15 & 288,50 & 295,37 & 4,04 & 1,62 & 2,38 \\
1200 & 80 & 120 & 450,23 & 418,44 & 443,04 & 7,60 & 1,62 & 5,88 \\
\hline
\end{tabular}

1. táblázat: $A z$ 1. föirány körüli hajlítórezgéshez tartozó sajátfrekvenciák

\begin{tabular}{|c|c|c|c|c|c|c|c|c|}
\hline \multirow{2}{*}{\multicolumn{3}{|c|}{ Geometriai méretek }} & \multicolumn{3}{|c|}{$\begin{array}{l}\text { 2. főirány körüli hajlítórezgéshez } \\
\text { tartozó sajátfrekvencia }\end{array}$} & \multicolumn{3}{|c|}{ Relatív eltérések [\%] } \\
\hline & & & \multirow{2}{*}{$\begin{array}{c}\text { Egyszabadságfokú } \\
\text { modell } \\
\mathrm{f}_{01,2} \\
{[\mathrm{~Hz}]} \\
\end{array}$} & \multirow{2}{*}{$\begin{array}{c}\begin{array}{c}\text { Szilárdtest } \\
\text { modell }\end{array} \\
\mathrm{f}_{\mathrm{Os}, 2} \\
{[\mathrm{~Hz}]} \\
\end{array}$} & \multirow{2}{*}{\begin{tabular}{|c|}
$\begin{array}{c}\text { Rúd } \\
\text { modell }\end{array}$ \\
$\mathrm{f}_{\mathrm{Or}, 2}$ \\
{$[\mathrm{~Hz}]$}
\end{tabular}} & \multirow{2}{*}{$\frac{f_{01,2}-f_{0 s, 2}}{f_{0 s, 2}} 100$} & \multirow{2}{*}{$\frac{\mathrm{f}_{01,2}-\mathrm{f}_{0 \mathrm{r}, 2}}{\mathrm{f}_{0 \mathrm{r}, 2}} 100$} & \multirow{2}{*}{$\frac{f_{0 r, 2}-f_{0 s, 2}}{f_{0 s, 2}} 100$} \\
\hline $\begin{array}{c}\mathrm{L} \\
{[\mathrm{mm}]}\end{array}$ & $\begin{array}{c}\mathrm{a} \\
{[\mathrm{mm}]}\end{array}$ & $\begin{array}{c}\mathrm{b} \\
{[\mathrm{mm}]}\end{array}$ & & & & & & \\
\hline 1000 & 40 & 40 & 216,11 & 211,16 & 212,66 & 2,34 & 1,62 & 0,71 \\
\hline 1000 & 40 & 60 & 216,11 & 211,47 & 212,66 & 2,19 & 1,62 & 0,56 \\
\hline 1000 & 40 & 80 & 216,11 & 211,83 & 212,66 & 2,02 & 1,62 & 0,39 \\
\hline 1000 & 40 & 100 & 216,11 & 212,22 & 212,66 & 1,83 & 1,62 & 0,21 \\
\hline 1000 & 80 & 80 & 432,22 & 410,77 & 425,32 & 5,22 & 1,62 & 3,54 \\
\hline 1000 & 80 & 120 & 432,22 & 411,86 & 425,32 & 4,94 & 1,62 & 3,27 \\
\hline 1200 & 40 & 40 & 150,08 & 147,03 & 147,68 & 2,07 & 1,63 & 0,44 \\
\hline 1200 & 40 & 60 & 150,08 & 147,22 & 147,68 & 1,95 & 1,63 & 0,32 \\
\hline 1200 & 40 & 80 & 150,08 & 147,43 & 147,68 & 1,80 & 1,63 & 0,17 \\
\hline 1200 & 40 & 100 & 150,08 & 147,67 & 147,68 & 1,63 & 1,63 & 0,01 \\
\hline 1200 & 80 & 80 & 300,15 & 288,50 & 295,37 & 4,04 & 1,62 & 2,38 \\
\hline 1200 & 80 & 120 & 300,15 & 289,17 & 295,37 & 3,80 & 1,62 & 2,14 \\
\hline
\end{tabular}

2. táblázat: A 2. föirány körüli hajlitórezgéshez tartozó sajátfrekvenciák

Az 1. és 2. táblázat alapján láthatjuk, hogy a végeselemes modális rezgésvizsgálatok alkalmazásával meghatározott-, és az egyszabadságfokú modellen végzett analitikus számítások eredményeként kapott sajátfrekvenciák, az általunk vizsgált esetekben nagyon közel estek egymáshoz. Megfigyelhető, hogy az egyszabadságfokú modellen számított sajátfrekvenciák bizonyultak a legnagyobbaknak, ezeket a rúd modell alapján számított értékek követték, míg a szilárdtest modell sajátfrekvenciái adódtak a legkisebbeknek. A fenti táblázatok összevetéséből kitűnik, hogy a numerikus modellek esetében sem függ a sajátfrekvencia értéke a téglalap keresztmetszet hajlítási tengellyel párhuzamos méretétől. Azonos hosszúságú gerendáknál, melyek hajlítási tengellyel párhuzamos mérete is megegyezik, rúd modelljeiknél századra pontos egyezést, a szilárdtest modelljeik esetében 1,06 Hz maximális eltérést tapasztaltuk a megfelelő sajátfrekvenciák között. (Az előbbi tulajdonság az analitikus modell esetében a (16) egyenletből következik.) Az egyszabadságfokú modellen kapott sajátfrekvenciák relatív eltérése a rúd modellen kapott értékektől 1,63\%, az általunk vizsgált példák esetében.

\section{6. Összefoglalás}

A megnövekedett számítási kapacitás és teljes, térbeli (globális) modellezést lehetővé tevő végeselem programok ellenére, fontosak az egyszerű, kéziszámításra alkalmas modellek. Tanulmányunkban a mindkét végén fix megtámasztású, téglalap keresztmetszetű gerendák hajlító rezgéséhez tartozó sajátfrekvenciáit határoztuk meg az alábbi módszerek szerint:

- egyszabadságfokú modell analitikus vizsgálata,

- térbeli szilárdtest modell végeselemes modális rezgésvizsgálata, 
- térbeli rúd modell végeselemes modális rezgésvizsgálata.

Cikkünkben arra kerestük a választ, mekkora eltérést kapunk a különböző módszerekkel számított értékek között. A maximális relatív eltérés a szilárdtest-, és az egyszabadságfokú modell között 10,25\%, míg a minimális relatív eltérés ugyanezen modellek között 1,63\%. Kisebb, 1,63\%-os relatív eltérést kaptunk a rúd-, és az egyszabadságfokú modellek között. (A pozitív előjelek azt mutatják, hogy minden esetben az egyszabadságfokú modellen kaptunk nagyobb frekvenciát.) Az általunk vizsgált esetekben, az alkalmazott paraméterek mellett, azt a következtetést vonhatjuk le, hogy közelítő méretfelvételnél, illetve fontos szerkezeti elemek véglegesített méreteinek kézi számítással történő ellenőrzésénél érdemes az egyszabadságfokú modellt alkalmazni. Ha a szilárdtest modell eredményét fogadjuk el a legpontosabbnak, akkor a példáink esetében azt láttuk, hogy a rúd-, és az egyszabadságfokú modellek szilárdtest modelltől való relatív eltérése közötti különbség 1,7\% körül van. Hangsúlyozzuk azonban, hogy ezek az eredmények elemszintű vizsgálatokhoz tartoznak, és nem helyettesítik az esetenként nagyon fontos globális szintű vizsgálatot.

\section{Hivatkozások}

[1] Zalka, K. (2012) Épületek komplex statikai vizsgálata. 2nd edn. Budapest.

[2] Tamás, P., Bojtos, A., Décsei-Paróczi, A., Fekete, R. T. (2014) Végeselem módszerek. BME MOGI.

[3] Györgyi, J. (2003) Dinamika. Budapest: Műegyetemi Kiadó.

[4] Vértes, G. (1976) Épületek dinamikája. Edited by E. Sajó and J. Molnár. Budapest: Műszaki Könyvkiadó.

[5] Kaliszky, S., Kurutzné Kovács, M. és Szilágyi, G. (2000) Szilárdságtan. Budapest: Nemzeti Tankönyvkiadó.

[6] AxisVM X5 felhasználói kézikönyv (2020). INTER-CAD Kft. 


\section{Függelék}

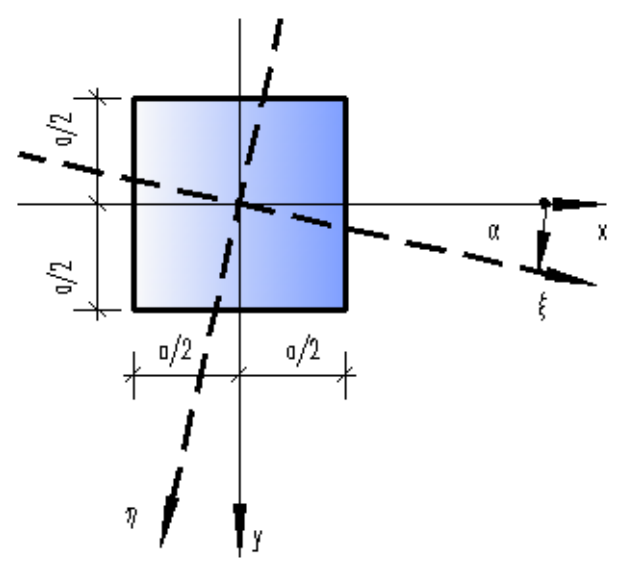

\section{F.1. ábra: a oldalú négyzet súlyponti koordináta rendszereiben}

Tekintsük az F.1 ábrán lévő $a$ oldalhosszúságú négyzetet. Az $x$ és $y$ tengelyek a négyzet megfelelő oldalfelező szimmetria tengelyeivel esnek egybe. A $x$; $y$ rendszert $\alpha$ szöggel elforgatva kapjuk a szintén súlyponti $\xi ; \eta$ rendszert. Ha ismertek az $x ; y$ rendszerben a másodrendú nyomatékok, az $I_{x}$ az $x$ tengelyre-, az $I_{y}$ az $y$ tengelyre vett inercia, valamint a $C_{x y}$ centrifugális nyomaték, a $\xi ; \eta$ rendszerben a másodrendű nyomatékokat, amik az $\alpha$ szög függvényei, [5] alapján a következő képletekkel határozhatjuk meg:

$$
\begin{gathered}
I_{\xi}(\alpha)=\frac{I_{x}+I_{y}}{2}+\frac{I_{x}-I_{y}}{2} \cdot \cos 2 \alpha-C_{x y} \cdot \sin 2 \alpha \\
I_{\eta}(\alpha)=\frac{I_{x}+I_{y}}{2}-\frac{I_{x}-I_{y}}{2} \cdot \cos 2 \alpha+C_{x y} \cdot \sin 2 \alpha \\
C_{\xi \eta}(\alpha)=\frac{I_{x}-I_{y}}{2} \cdot \sin 2 \alpha+C_{x y} \cdot \cos 2 \alpha
\end{gathered}
$$

Mivel az $x$ és $y$ tengelyek (a szimmetria miatt) tehetetlenségi fóirányok, a centrifugális nyomaték ebben a rendszerben zérus. Felhasználva, hogy $I_{x}=I_{y}=a^{4} / 12$ illetve $C_{x y}=0$, az (F1), (F2) és (F3) egyenletek az alábbi egyszerúbb formákban írhatók:

$$
\begin{aligned}
& I_{\xi}(\alpha)=\frac{a^{4}}{12} \\
& I_{\eta}(\alpha)=\frac{a^{4}}{12} \\
& C_{\xi \eta}(\alpha)=0 .
\end{aligned}
$$

Az (F6) egyenlet alapján látható, hogy az összes súlyponti irány főirány, hiszen a centrifugális nyomaték az $\alpha$ szög értékétől függetlenül 0 . Az (F4) és (F5) kifejezésekből következik, hogy bármely súlyponti tengelyre vett inercia értéke $a^{4} / 12$. Ezek alapján kimondhatjuk általánosan, ha egy síkidom súlyponti tehetetlenségi főnyomatékai egyenlőek, azaz $I_{1}=I_{2}$, ebben az esetben a súlyponti tengelyekre vett inerciák nagysága állandó és minden irány főirány. Minden síkidom esetében létezik legalább két súlyponti tehetetlenségi főirány, ha a tehetetlenségi főnyomatékok ezekben megegyeznek, akkor 
International Journal of Engineering and Management Sciences (IJEMS) Vol. 6. (2021). No. 3

DOI: 10.21791/IJEMS.2021.3.6.

végtelen sok fóirány van, hiszen ekkor bármely súlyponti rendszerben a centrifugális nyomaték 0 , így minden irány főirány és az inercia értéke állandó. Ez utóbbi teljesül a négyzetek, a négyzetes zártszelvények, a körök valamint a csőszelvények esetében. 